\title{
ДИЗАЙН, СИНТЕЗ И ПРОТИВООПУХОЛЕВАЯ АКТИВНОСТЬ НОВЫХ N-АЦИЛЗАМЕЩЕННЫХ 3-АРИЛ-4-АМИНОИЗОКСАЗОЛОВ
}

\section{К.С. Садовников ${ }^{1}$, Д.А. Василенко', Н.А. Зефиров', О.Н. Зефирова ${ }^{1,2}$, Ю.А. Грачева', Е.Р. Милаева ${ }^{1,2}$, А.С. Бунев ${ }^{3}$, Е.Б. Аверина ${ }^{1,2}$}

${ }^{1}$ Химический факультет, Московский государственный университет им. М.В. Ломоносова, 119991, Россия, Москва, Ленинские горы, 1-3.

${ }^{2}$ Институт физиологически активных веществ, Российская академия наук, 142432, Россия, Черноголовка, проспект Северный, 1.

${ }^{3}$ Центр медицинской химии, Тольяттинский государственный университет, 445020, Россия, Тольятти, Белорусская, 14.

DOI: 10.19163/MedChemRussia2021-2021-348

E-mail:11seconds@mail.ru

Производные изоксазола широко используются для поиска новых эффективных противоопухолевых агентов с улучшенным фармакокинетическим профилем [1]. В рамках данной работы был осуществлен направленный синтез библиотеки замещенных изоксазолов 1 , которые представляли интерес в качестве лигандов колхицинового сайта белка тубулина. Новые производные изоксазола 1 были получены по разработанной нами синтетической схеме, включающей гетероциклизацию арил\гетарилзамещенных $\alpha, \beta$-ненасыщенных кетонов под действием трет-бутилнитрита, восстановление нитрогруппы образующихся 4-нитроизоксазолов 2 и последующее ацилирование 4-аминогруппы гетероциклов 3 хлорангидридами ароматических кислот.

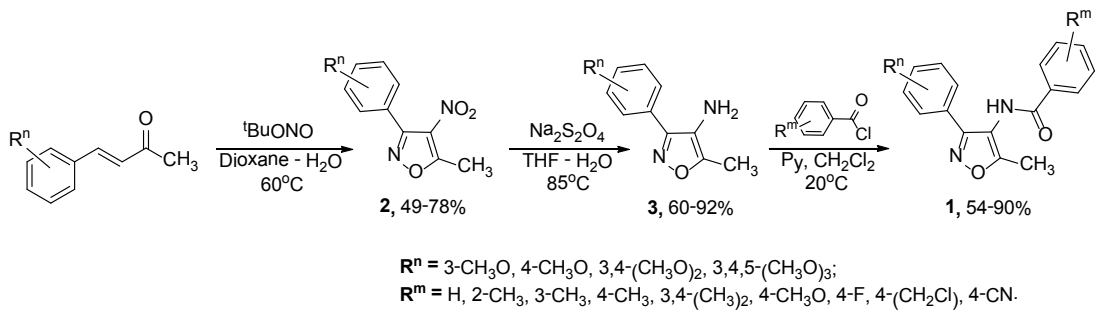

Для всех синтезированных гетероциклов 1 была изучена противоопухолевая активность на различных раковых клеточных линиях (LNCap, A-375, A431, PC3, HCT 116, A549 и др.), а также изучено действие на сеть микротрубочек клеток A549. Найдены соединения, проявляющие активность в наномолярном диапазоне концентраций.

Работа выполнена при финансовой поддержке РНФ (грант 19-13-00084).

\section{Литература}

[1] J. Zhu, J. Mo, H. Lin, Y. Chen and H. Sun, Bioorg. Med. Chem. 2018, 26, 3065-3075.

$$
-348-
$$

